\title{
THE EFFECTIVENESS OF 5E LEARNING CYCLE MODEL TOWARD MATHEMATICS LEARNING OUTCOMES OF STUDENT GRADE VII AT SMP MUHAMMADIYAH 2 KALASAN
}

\author{
Indah Fitria Noor Arifina ${ }^{a}$, Nur Arina Hidayati. ${ }^{b}$ \\ Program Studi Pendidikan Matematika FKIP UAD \\ Jalan Ring Road Selatan, Tamanan, Banguntapan, Bantul Yogyakarta \\ aindahfitria378@gmail.com, bnur.hidayati@pmat.uad.ac.id
}

\begin{abstract}
This research was done because there are many students who are less active and less enthusiastic in learning process. Students are reluctant to ask about the material they have not understood that the learning outcomes obtained are less optimal. This research aims to determine the effectiveness of mathematics learning by using Learning Cycle $5 \mathrm{E}$ model toward learning outcomes of students' mathematics of class VII SMP Muhammadiyah 2 Kalasan district Sleman in Even Semester in Academic Year 2015/2016. This was control group posttest only. The population in this research were students class VII SMP Muhammadiyah 2 Kalasan district Sleman. Samples were taken using random sampling techniques derived class VII A as an experimental class and class VII C as the control class. The data collection is done with test method. Testing instrument using validity and reliability. Data were analyzed using analysis prerequisite test including normality test with the formula Chi-square, homogeneity test by test Bartlett, and hypothesis testing with t-test. Based on calculations by the significant level $\alpha=5 \%$ and the degrees of freedom 58, we concluded that: (1) There is differences in learning outcomes of students learning math using Learning Cycle 5E Instructional Model with learning using direct Learning Model. This is indicated by the results of the first test of the hypothesis that $t_{\text {count }}=2,406>t_{\text {table }}=2,002$ (2) learning using Learning Cycle 5E Instructional Model is more effective than learning using direct Learning Model. It is shown on the second hypothesis that the test results $t_{\text {count }}=2,406>t_{\text {table }}=1,671$.
\end{abstract}

Keywords: Effectiveness, Mathematics Learning Outcomes, Learning Cycle 5E Model

\section{INTRODUCTION}

Education is very important for the survival of a nation, because Education functions to educate the life of the nation. With the quality of good education, a nation can improve the welfare of its citizens so they have a decent livelihood. In Indonesia education is carried out through formal education and non-formal education. Formal education is education held in schools in general, while non-formal education is a pathway to education outside formal education which can be carried out in a structured and tiered manner. Through education, aspects of life can be developed through the learning process. The success of the learning process is the main goal in formal education, namely at school. In order for the learning process to succeed, an appropriate learning model is needed so that communicative and effective interactions between teachers and students are established.

Based on the results of observations on October 30, 2015 in class VII students of SMP Muhammadiyah 2 Kalasan, Sleman Regency on mathematics learning it was known that some students did not like mathematics because they were considered difficult so they were lazy to learn mathematics and students were less enthusiastic during the mathematics learning process. If the teacher gives homework, Some students still do not do it, there are also those who work in the class before the lesson starts or cheat on the work of other friends. The learning process of mathematics in SMP Muhammadiyah 2 Kalasan Sleman Regency used direct learning where the learning process is teachercentered. When learning in the classroom the teacher explains more about the material while the students listen, take notes and then do the exercises. With learning like this, student participation and activity in the learning process is not optimal. Students are reluctant to ask if given the opportunity to ask questions that have not been understood so that the results of their learning are not optimal. 
Based on the evaluation of middle semester of students in grade VII of SMP Muhammadiyah 2 Kalasan Sleman Regency in academic year 2015/2016 on mathematics subjects, showed that there were still many mathematics learning outcomes of class VII students below the minimum completeness criteria (MCC) which were able to reach 75,0. Based on these conditions, the teacher must be able to choose and use a learning model that is suitable for improving student learning outcomes. In this case, the teacher is required to know, choose, and be able to apply learning models that are considered effective so that more meaningful learning is created with a conducive learning atmosphere and can provide opportunities for students to exchange opinions, cooperate with friends, interact with teachers, respond to thoughts other students, so students can remember longer what they have learned.

One model that is thought to be able to create a conducive learning atmosphere and able to create meaningful learning and support student activity, namely the Learning Cycle learning model. According to Wena, Made (2013, p. 170) 5E Learning Cycle model is one of the learning models with constructivist approaches. Constructivist learning is based on constructivism ideology where knowledge is not from outside but from within and arises from experience based cognitive construction. In teacher learning it is no longer the only source of information, but the teacher is more positioned as a facilitator that facilitates students to be able to learn and construct their own knowledge and students learn with small groups to share ideas during discussion so that student activity can be seen. So knowledge is built by students so students can better remember and master the material in learning.

In line with this, Mutoharoh, Navis (2015) showed that the mathematics learning outcomes of students using the 5E Learning Cycle model were more effective than the mathematics learning outcomes of students using the Group Investigation learning model. In addition, Indriati, Desi (2015) shown that mathematics learning outcomes of students who use the 5E Learning Cycle model are more effective than students' mathematics learning outcomes without using the 5E Learning Cycle model.

From the description above, this study aims to determine whether or not there is a difference between the mathematics learning outcomes of students who use the 5E Learning Cycle model and student mathematics learning outcomes without using the 5E Learning Cycle model, and to find out more effectively between 5E Learning Cycle model and without using the 5E Learning Cycle model on mathematics learning outcomes of seventh grade students of SMP Muhammadiyah 2 Kalasan Sleman Regency in even semesterin academic year 2015/2016.

\section{METHODS}

The type of research is an experimental research. This study used two classes, the experimental class is treated using the 5E Learning Cycle model while the control class used the Direct learning model. The research design used is True Experimental Design with the type of Postest-Only Control Design. The design of this study is illustrated as Table 1.

Table 1.Research design

\begin{tabular}{llcc}
\hline & Group & Treatment & Posttest \\
\hline $\mathbf{R}$ & Experiment & $X$ & $O_{1}$ \\
$\mathbf{R}$ & Control & - & $O_{2}$ \\
\hline
\end{tabular}

Information:

$\begin{array}{ll}\text { Experiment } & : \text { Classes that use 5E Learning Cycle model } \\ \text { Control } & : \text { Classes that use the direct learning model } \\ R & : \text { Random } \\ X & : \text { There is a treatment using the 5E Learning Cycle model } \\ - & : \text { There is no treatment } \\ \mathrm{O}_{1} & : \text { Results of the experimental class posttest } \\ \mathrm{O}_{2} & : \text { Results of posttest control class }\end{array}$

(Sugiyono, 2015, p.112) 
This research was conducted at SMP Muhammadiyah 2 in Kalasan, Sleman Regency. The time used for data collection in this study is the even semester of academic year 2015/2016. Which consisted of 5 classes, namely class VII A, VII B, VII C, VII D, and VII E. Samples were taken 2 classes using random sampling technique, obtained class VII $\mathrm{A}$ as the experimental class and class VII $\mathrm{C}$ as the control class.

Data collection techniques used are observation methods and test methods. Observations used in the form of the results of observation activities of mathematics learning activities of class VII students of SMP Muhammadiyah 2 Kalasan to find out the conditions during learning. While the test in the form of a learning outcome test (posttest) was given after being treated with the 5E Learning Cycle model. The instrument used was a learning outcome test on the subject of Quadrilateral in the form of a test of mathematics learning outcomes. Before being tested in the experimental class, so that the learning outcome test questions are arranged not to deviate from the material to be taught, then a grid is made, test test questions, and review the items of the test results of mathematics learning. After the test instruments were arranged, then tested on the instrument trial class, namely class VII B. After the test questions were tested, the test items were analyzed by validity test using the product moment correlation formula, the discriminating power using the discrimination index formula, and the reliability test using the formula Kuder Richadson-20 (KR-20). Analysis prerequisite test used normality test with ChiSquare test and homogeneity test with Bartlet test. Hypothesis testing is used by both parties and one party.

\section{RESULTS AND DISCUSSION}

Based on the research that has been carried out obtained data in the form of initial abilities and student learning outcomes. The summary results of the normal ability normality test can be seen in Table 2.

Table 2. Summary of Normality Test Results Initial Capability of Early Capabilities

\begin{tabular}{lll}
\hline Class & $\chi_{\text {count }}^{2}$ & \multicolumn{1}{c}{$\chi_{\text {table }}^{2}$} \\
\hline Experiment & $\mathbf{0 , 7 9 8}$ & $\mathbf{7 , 8 1 5}$ \\
Control & $\mathbf{0 , 8 8 9}$ & $\mathbf{7 , 8 1 5}$ \\
\hline
\end{tabular}

From the normality test at a significant level of $5 \%$ and the degree of freedom $=3$, it can be seen that $\chi_{\text {count }}^{2}=0.798$ and $\chi_{\text {table }}^{2}=7.815$,so that $\chi^{2}{ }_{\text {count }}<$ $\chi_{\text {table }}^{2}$ meaning that the experimental class has initial capability data that is normally distributed. While the normality test at a significant level of $5 \%$ and degrees of freedom $=3$, it can be seen that $\chi_{\text {count }}^{2}=$ 0,889 and $\chi_{\text {table }}^{2}=7,815$, so that $\chi_{\text {count }}^{2}<\chi_{\text {table }}^{2}$ it means that the control class has initial ability data that are normally distributed.

The summary results of the initial homogeneity test can be seen in Table 3 .

Table 3.Summary of Initial Ability Homogeneity Test Results

\begin{tabular}{cc}
\hline$\chi_{\text {count }}^{2}$ & $\chi_{\text {table }}^{2}$ \\
\hline 0,756 & 3,841 \\
\hline
\end{tabular}

From the homogeneity test at a significant level of 5\% and degrees of freedom $=1$, it can be seen that $\chi_{\text {count }}^{2}=0.756$ and $\chi^{2}{ }_{\text {table }}=3.841$, so $\chi_{\text {count }}^{2}<\chi^{2}{ }_{\text {table }}$ meaning that both classes have the same variance (homogeneous).

The summary of the results of the hypothesis test the similarity of the initial capabilities can be seen in Table 4. 
Table 4.Summary of Initial Capability Equity Hypothesis Test Results

\begin{tabular}{cc}
\hline $\boldsymbol{t}_{\text {count }}$ & $\boldsymbol{t}_{\text {table }}$ \\
\hline 1,689 & 2,002 \\
\hline
\end{tabular}

From the hypothesis test similarity at 5\% significance level and degree of freedom $=58$, it can be seen that $\boldsymbol{t}_{\text {count }}=1.689$ and $\boldsymbol{t}_{\text {table }}=2.002$,so $\boldsymbol{t}_{\text {count }}<\boldsymbol{t}_{\text {table }}$ which means there is no difference between the initial ability of students using the $5 \mathrm{E}$ Learning Cycle model and students' initial abilities without using the 5E Learning Cyclemodel for students of SMP Muhammadiyah 2 Kalasan Sleman regency in VII grade of even semester in academic year 2015/2016.

The summary test for normality of learning outcomes can be seen in Table 5.

Table 5.Summary of the Normality of Learning Outcomes

\begin{tabular}{lll}
\hline Class & $\chi_{\text {count }}^{2}$ & $\chi_{\text {table }}^{2}$ \\
\hline Experiment & $\mathbf{0 , 3 3 5}$ & $\mathbf{7 , 8 1 5}$ \\
Control & $\mathbf{2 , 8 6 3}$ & $\mathbf{7 , 8 1 5}$ \\
\hline
\end{tabular}

From the normality test at a significant level of $5 \%$ and degrees of freedom $=3$, it can be seen that $\chi_{\text {count }}^{2}=0.335$ and $\chi_{\text {table }}^{2}=2.863$, so $\chi_{\text {count }}^{2}<\chi^{2}{ }_{\text {table }}$ which means that the experimental class has learning outcomes data that are normally distributed. While the normality test at a significant level of $5 \%$ and degrees of freedom $=3$, it can be seen that $\chi^{2}{ }_{\text {count }}=0.335$ and $\chi^{2}{ }_{\text {table }}=7.815$, so $\chi_{\text {count }}^{2}$ $\chi^{2}{ }_{\text {table }}$ which means the control class has data on learning outcomes that are normally distributed.

The summary test of homogeneity of learning outcomes can be seen in Table 6 .

Table 6. Summary of Homogeneity Test of Learning Outcomes

\begin{tabular}{ll}
\hline$\chi_{\text {count }}^{2}$ & $\chi_{\text {table }}^{2}$ \\
\hline 1,848 & 3,841 \\
\hline
\end{tabular}

From the homogeneity test at a significant level of 5\% and degrees of freedom $=1$, it can be seen that $\chi^{2}{ }_{\text {count }}=1,848$ and $\chi^{2}{ }_{\text {table }}=3,841$, so that $\chi^{2}{ }_{\text {count }}<\chi^{2}{ }_{\text {table }}$ meaning that both classes have the same variance (homogeneous).

The summary of the results of the first hypothesis test can be seen in Table 7 .

Table 7. Summary of Test of Two side Hypothesis

\begin{tabular}{cc}
\hline $\boldsymbol{t}_{\text {count }}$ & $\boldsymbol{t}_{\text {table }}$ \\
\hline 2,406 & 2,002 \\
\hline
\end{tabular}

From the two-sidechypothesis test at a significant level of 5\% and the degree of freedom $=58$, it can be seen that $\boldsymbol{t}_{\text {count }}=2.406$ and $\boldsymbol{t}_{\text {table }}=2.002$, so $\boldsymbol{t}_{\text {count }}>\boldsymbol{t}_{\text {table }}$ which means there is a difference between the mathematics learning outcomes of students who use the 5E Learning Cycle model students without using the 5E Learning Cycle model for class VII students of SMP Muhammadiyah 2 Sleman Regency in even semesterof academic year 2015/2016.

After it is known that there is no difference between the mathematics learning outcomes of the experimental class students and the control class, then one side hypothesis testing is carried out, can be seen in Table 8. 
Table 8. Summary of One-side Hypothesis Test

\begin{tabular}{cc}
\hline $\boldsymbol{t}_{\text {count }}$ & $\boldsymbol{t}_{\text {table }}$ \\
\hline 2,406 & 1,671 \\
\hline
\end{tabular}

From the second hypothesis test at a significant level of $5 \%$ and freedom degree $=58$, it can be seen that $\boldsymbol{t}_{\text {count }}=2.406$ and $\boldsymbol{t}_{\text {table }}=1.671$, so $\boldsymbol{t}_{\text {count }}>\boldsymbol{t}_{\text {table }}$ which means the 5E Learning cycle model is more effective than students' mathematics learning outcomes without using the $5 \mathrm{E}$ Learning Cycle model on the mathematics learning outcomes of class VII students of SMP Muhammadiyah 2 Kalasan Sleman Regency in even semester of academic year 2015/2016.

\section{CONCLUSION}

The conclusion of this research are:

1. There is a difference between the mathematics learning outcomes of students who use the $5 \mathrm{E}$ Learning Cycle model and students' mathematics learning outcomes without using the 5E Learning Cycle model for class VII students of SMP Muhammadiyah 2 Kalasan Sleman Regency in even semester of academic year 2015/2016. This is indicated by the results of the two-side hypothesis test with a significant level of $5 \%$ and 58 degrees of freedom, obtained by the value $t_{\text {count }}=2,406$ and $t_{\text {table }}=2,002$. Where $t_{\text {count }}>t_{\text {table }}$ so that $\mathrm{H}_{0}$ is rejected and $\mathrm{H}_{1}$ is accepted.

2. 5E Learning Cycle model is more effective than without using the 5E Learning Cycle model on mathematics learning outcomes of class VII students of SMP Muhammadiyah 2 Kalasan Sleman Regency in even semester of academic year 2015/2016. This is indicated by the results of the oneside hypothesis test with a significant level of $5 \%$ and 58 degrees of freedom, obtained by the value $t_{\text {count }}=2,406$ and $t_{\text {table }}=1.671$. Where $t_{\text {count }}>t_{\text {table }}$ so that $\mathrm{H}_{0}$ is rejected and $\mathrm{H}_{1}$ is accepted.

\section{SUGGESTION}

Based on the conclusions above, then some suggestions that researchers can express for the following are:

1. Use the 5E Learning Cycle 5E model so that it can be used as an alternative learning model in the classroom. However, it should take into many time when learning is done.

2. Before implementing the 5E Learning Cycle model, teachers are required to master the steps and learning material so that learning will be better planned.

3. The research conducted is limited to the subject of Quadrilateral so that it is expected that other researchers will be able to expand the problem, for example, can be applied to other materials and even wider samples.

\section{REFERENCES}

Indriati, Desi. 2015. Efektivitas Model Pembelajaran Learning Cycle Terhadap Kemampuan Berpikir Kreatif Siswa Kelas VIII SMP Muhammadiyah 9 Yogyakarta Semester Genap Tahun Ajaran 2014/2015. Skripsi S1. Universitas Ahmad Dahlan.

Mutoharoh, Navis. 2015. Efektivitas Model Pembelajaran Learning Cycle 5E dan Group Investigation (GI) Terhadap Hasil Belajar Matematika Siswa Kelas VIII SMP Negeri 2 Mandiraja Kabupaten Banjarnegara Semester Genap Tahun Ajaran 2014 / 2015. Skripsi S1. Universitas Ahmad Dahlan.

Sugiyono. 2008. Metode Penelitian (Kuantitatif Kualitatif dan R\&D). Jakarta : Alfabeta.

Wena, Made. 2013. Strategi Pembelajaran Inovatif Kontemporer. Jakarta : PT Bumi Aksara. 